concerned with common movements made without visual guidance, and he measured the response time in blind positioning reactions made in various emergency conditions.

Two French investigators, C. Benassy-Chauffard and J. Pelnard, analysed the occupational mobility of young workers by the use of methods (developed by Dr. J. M. Faverge) based on the theory of information, whereby the importance of both personal and social factors is assessed. An instructive report on workers' mobility in north Italy was provided by M. Cesa-Bianchi and E. Spaltro. A fresh approach to the study of vocational interests was made by A. Rodger, S. Wiegersma and L. Ancona.

In the medical sessions Prof. L. S. Hearnshaw and H. D. Paul described the present position of psychology in British and German medical schools, respectively. The wide interest in the effects of hospitalization was shown by studies from France, Czechoslovakia, Italy and Great Britain. G. Trentini discussed the immediate effects of hospitalizing cancerous patients. The impact of hospitalization on young children who are chronic invalids or who suffer from organic disability was described by $\mathbf{R}$. Gaddini and Prof. R. W. Pickford. The latter also explained the principles on which successful psychotherapy was based. A first report on the usefulness of training courses by correspondence for patients staying for long periods in British hospitals was given by Dr. H. G. Maule.

Material of a different type was offered by Prof. O. Miyagi, of Tokyo, in the form of a clinical analysis of social pathology in which he contrasted the forms and incidence of mental disorder encountered in Japan with those met in Europe. He also cited characteristic war-time rumours occurring in Japan and compared them with those found by Prof. G. W. Allport among Americans in war-time. Other noteworthy papers included an experimental study by Mr. P. Sainsbury, who claimed, on the basis of electromyographic observations, that individuals tend to preserve a fairly constant level of muscle tension, as Freud suggested, and that gestural movements also have a characteristic level in the individual, such movements as well as conversational gestures increasing in states of anxiety.

An important session on educational psychology was devoted to a symposium on the evaluation of educational achievement ('docimology') presided over by Prof. R. Bonnardel. Other interesting papers were read by Prof. P. E. Vernon on the assessment of higher intellectual qualities, by Mme. TabouretKeller on the elimination of errors in orthography, by Mrs. T. G. Thurstone on the improvement of verbal comprehension, and by Prof. Rosca from Roumania on the effect of alternating activities on proficiency in school-work. He showed by careful experiments that the alternation of activities belonging to different (Pavlovian) signal systems is more efficacious than alternation within the same system.

Far fewer papers were devoted to legal psychology than to the other three themes, but a wide range of subjects revealed growing interest in this field. Apart from the topics already mentioned above, one session was concerned with social influences on delinquency with reports by G. Cohen-Séat, E. Valentini, F. Rabaye and F. M. Raeven on favourable and adverse features in the influence of the cinema. New light on the mind of the homicide was thrown by Dr. A. Paolella's study of projective tests administered to a group of twenty murderers and by Dr. A. Ginsberg's comparable investigation of a mixed group of criminals. A valuable paper on correctional psychology, based on extensive experience at one of the most advanced prisons in Switzerland, was provided by W. Haesler.

It only remains to add that the location of the Congress provided the participants with excellent opportunities for refreshing their memories of the Forum Romanum as well as stimulating their scientific and professional interest in newer developments in applied psychology.
JOHN COHEN

\title{
DEVELOPMENT OF THE WEST AFRICAN ENVIRONMENT
}

$\mathrm{T}$ HE second Interterritorial Conference of the West African Science Association was held at the University College of Ghana during March 23-29. The theme discussed was "The Development of the West African Environment", and with the aid of a grant from the Rockefeller Foundation, the Association was able to invite a number of scientists noted for their work in this field. The early history of the environment was discussed in relation to the geology, pedology, archæology and palæontology of the region, and its more recent history in relation to plant and animal ecology. Papers were also presented on the effects of recent biotic influences.

Investigations in the south-western Sahara carried out by Prof. Th. Monod, director of the Institut Français d'Afrique Noire, and M. R. Mauny, head of its Department of Prehistory and Archæology, showed how in this region relatively slight climatic changes between ar:d and semi-arid have resulted in marked changes in the flora and fauna. Such changes have also determined the course of human migrations in much of West Africa.

Dr. J. D'Hoore, of the Service Pédologique Interafricain, discussed the many factors involved in the interpretation of the formation of tropical soils, with special reference to the time factor. Further fundamental studies on the processes involved will be necessary before proper understanding of the changes caused in soils by the succession of dry and wet periods is obtained. There is, however, clear evidence from studies of pedogenesis that almost all forest areas of Africa have been subjected to dry periods, and that areas now dry have been under forest. Dr. W. Bruckner and Mr. O. Davies, both of the University College of Ghana, presented the evidence at present available concerning the changes that have taken place in the West African environment as shown by mantle rock and archæological studies in Ghana. Their evidence showed that the succession of pluvial and interpluvial periods in West Africa has followed a course similar to the glacial and interglacial periods in temperate regions. But, as Dr. L. S. B. Leakey, curator of the Coryndon Museum, Nairobi, emphasized, until much more evidence is gathered, reliable correlations between the evidence available from different sciences, and between, for example, East and West Africa, will be very difficult to achieve. 
M. André Aubréville, formerly inspecteur-général des eaux et forêts de France Outre-mer, described how the influence of past climates is still apparent in the existence of relict species and savannah areas within what is now the high rain forest zone. But in a paper entitled "Derived Savannah-Derived from What ?" by Mr. R. W. J. Keay, principal research officer in the Nigerian Forest Research Department, the difficulty of distinguishing between relict and derived savannah areas was emphasized. The influence of man on the environment was also discussed by Prof. J. F. V. Phillips, of the University College of Ghana. It was apparent that much further work would be necessary before the relative importance of climatic changes and the activities of man on the vegetation of West Africa could be defined.

The probable relations of climatic and vegetational changes to the distribution of the mammalian fauna in past and present times was described by M. P. L. Dekeyser, head of the Zoology Section of the Institut Français d'Afrique Noire, and in a paper by the late Mr. Angus Booth. Mr. Booth, who was lecturer in zoology in the University College of Ghans and secretary to the Conference, died on March 16 after s short illness. During his six years in West Africa he had become the leading authority on West African primates.

In these papers the presence of relict faunas and the distribution of mammalian fossils provided further evidence for a succession of pluvial and interpluvial periods, but once again the dating of these periods was extremely difficult.

In summary, it may be said that while there was no indication of any disagreement in the probable succession of climatic changes as proposed by Sir George Simpson in his "Further Studies on World Climate" (Quart. J. Roy. Meteor. Soc., 83, 459; 1957), and ample evidence from a variety of sources to substantiate the theory that a succession of pluvial and interpluvial periods has occurred in the tropics, corresponding to the glacial periods of the temperate zone, further fundamental research into the geology, pedology, archæology, phytogeography and zoogeography is necessary before any well-defined chronological sequence can be established. The great. importance of the succession of pluvial and interpluvial periods to a proper understanding of the natural history of this and other parts of Africa is very evident.

D. J. Greentand

\section{AFRICAN CATTLE IN BRITISH DEPENDENT TERRITORIES}

$T$ HE primary purpose of a survey carried out by D. E. Faulkner, director of veterinary services, Nyasaland, and Dr. H. Fpstein, of the Hebrew University, Israel, was to describe the distinctive types and breeds of indigenous cattle found in British Dependent Territories of Africa*. Besides those of the Colonial territories, descriptions are included of the indigenous cattle of Southern Rhodesia (a selfgoverning British colony), the High Commission territories of Bechuanaland, Basutoland and Swaziland, and also of Libya and the Sudan. The cattle of the latter countries have been included because they help to throw light on the origins of the cattle of the Colonial territories adjacent or near them.

So far as possible, the types and breeds of cattle are described separately regardless of their territorial origin. In some cases it has been necessary to provide explanatory notes on the indigenous cattle of certain individual territories to make the existing situation clear. In the case of the Bechuanaland Protectorate and Southern Rhodesia, for example, owing to various historical movements and introduction of stock, the position would be confused without knowledge of the historical background.

The system of grouping and classification employed is as follows : all cattle have been grouped into three main geographical regions comprising East, Central and South Africa; West Africa; and North Africa.

The first of these regions, namely East, Central and South Africa, consists of three areas which are large and important regions in themselves. For the purpose of the survey it seemed better to group the three together in view of the extensive migratory movements of man and animals which, over the centuries,

* Colonial Office : Colonial Advisory Council of Agriculture, Animal Health and Forestry. Publication No. 5: The Indigenons Cattle of the British Dependent Territories in Africa, with material on certain other African Countries. Pp. xvili +18 and commencing in East Africa, have occurred in great waves down the continental backbone through central Africa to the south.

The origin and history of African cattle are dealt with in some detail. Epstein has devoted considerable study over many years to this most important subject and the form of classification employed in the publication is almost entirely the result of his work.

The foundation groups into which the various types have been classified are as follows:

\section{Humpless cattle:}

Longhorn humpless

Shorthorn humple.

Humped cattle :

Zebu cattle (1) Cervico-thoracic humped (neck-humped).

(2) Thoracic-humped (chest humped).

Sanga cattle (1) Cervico-thoracic humped (neck-humped). (2) Thoracic-humped (chest-humped).

In some regions no representatives of a group as such are now to be found, examples of this being the absence of longhorn humpless cattle in East, Central and South Africa, of the cervico-thoracic humped zebu in West Africa, and in North Africa the absence of every group except the shorthorn humpless cattle represented by the Libyan shorthorn.

Knowledge of the origin and history of African cattle types can play an important part in the efforts being made to improve them. From a slight study of the basic foundation groups from which the present breeds and sub-types of Africa have sprung, it is apparent that certain fundamental differences exist between them. To appreciate the genetical potentialities of these breeds and types it is important to know as much as possible not only of the parent stocks from which they came, but of the environmental conditions under which they and their parent stocks developed. Such knowledge is also of value when assessment has to be made of the effects of cross-breeding which has taken place over a long period between various breeds and sub-types. 